\title{
Ekspresi Relatif mRNA LMP1 Epstein-Barr Virus dari Jaringan Tumor Terfiksasi Formalin dalam Blok Parafin sebagai Biomarker Progresivitas Tumor pada Karsinoma Nasofaring Tidak Berdiferensiasi
}

\author{
Daniel Joko Wahyono ${ }^{1}$, Arundito Widikusumo ${ }^{2}$, Hidayat Sulistyo ${ }^{3}$ \\ ${ }^{1)}$ Fakultas Biologi, Universitas Jenderal Soedirman, Purwokerto, Indonesia \\ ${ }^{2)}$ Bagian/Poli Radioterapi, RSUD Prof dr Margono Soekarjo, Purwokerto, Indonesia \\ ${ }^{3)}$ Bagian Patologi Anatomi, Fakultas Kedokteran, Universitas Jenderal Soedirman, \\ Purwokerto, Indonesia \\ Email : danieljokowahyono13@gmail.com
}

\begin{abstract}
Nasopharyngeal carcinoma (NPC) is a multifactorial disease that is geographically endemic in the world. Indonesia population is about 225 million people having varied diversity ethnic and has the high incidence rate of NPC approximately 6.2 per 100,000 people per year. EBV infection has been shown to be consistent with the onset of NPC. The pathogenesis of NPC is more directly reflected by carcinoma-specific viral transcriptional activity at the site of primary tumor. Therefore, EBV infection in NPC is also reflected by the expression of EBV latent and lytic gene, particularly in the expression of mRNA LMPI EBV as a biomarker for EBV latent infection. The aims of this study were to determine the relative expression of mRNA LMPI EBV in undifferentiated NPC (NPC WHO-III) patient as a biomarker of tumour progressivity in NPC. The samples were the tissue biopsies formalin-fixed embedded paraffin (FFPE) of 28 undifferentiated NPC patients at Pathology Anatomy Departement, R.S.U.D. Prof. dr. Margono Soekarjo, Purwokerto. The relative expression of mRNA LMPI EBV was determined by RT-qPCR technique and calculated by formula $2^{-4 C t}$. The relative expression of mRNA LMPI EBV in undifferentiated NPCpatients on advanced staging was approximately start from 5,832.90 to 39,786.70. In undifferentiated NPC patients, the relative expression of mRNA LMP1 EBV in stadium IV $(13.619,33 \pm 4902,3)$ increased of 1.5 times compared to stadium III $(n=2 ; 9.299,35 \pm 6178,9)$, however it was no significance differences statistically. Therefore, the relative expression of mRNA LMPI EBV has a potensial biomarker of tumour progressivity in advanced staging undifferentiated NPC.
\end{abstract}

Key word : relative expression of mRNA LMP1 EBV, FFPE tissue biopsy, tumor progressivity biomarker, Undierentiated NPC (NPC WHO-III)

\begin{abstract}
Abstrak
Karsinoma Nasofaring (KNF) merupakan penyakit yang bersifat multifaktor dan endemik di dunia. Populasi penduduk Indonesia yang berjumlah 225 juta yang terdiri atas beragam etnis populasi memiliki laju insidensi kasus KNF yang tinggi berkisar 6,2 per 100.000 penduduk pertahun. Infeksi EBV terbukti konsisten dengan perkembangan KNF. Patogenesis KNF lebih nyata terlihat dari aktivitas spesifik transkripsi virus pada tumor primernya. Infeksi EBV pada KNF dapat diamati dari ekspresi gen laten dan litiknya.. LMP1 merupakan onkogen utama dalam tumorigenesis KNF, sehingga ekspresi mRNA LMP1 EBV berperan sebagai petanda biologi infeksi laten EBV. Penelitian ini adalah untuk mengetahui ekspresi relatif mRNA LMP1 EBV berpotensi sebagai biomarka progresivitas tumor pada KNF tidak berdiferensiasi (KNF WHO III) Desain penelitian ini adalah studi cross sectional (seran lintang). Subyek penelitian adalah 28 biopsi jaringan tumor nasofaring yang terfiksasi dalam blok paraffin (formalin-fixed paraffin embedded/FFPE) populasi pasien KNF tidak berdiferensiasi pada Poli Patologi Anatomi R.S.U.D. Prof dr. Margono Soekarjo - Fakultas Kedokteran Unsoed, Purwokerto. Ekspresi relatif mRNA LMP1 EBV ditentukan dengan teknik RT-qPCR dan dihitung dengan rumus $2^{-\Delta \mathrm{Ct}}$. Nilai ekspresi relatif mRNA LMP1 EBV pada penderita KNF tidak berdiferensiasi stadium lanjut berkisar 5,832.90 - 39,786.70. Nilai ekspresi relatif mRNA LMP1 EBV pada stadium IV $(13.619,33 \pm 4902,3)$ meningkat 1,5 kali dibandingkan dengan stadium III $(9.299,35 \pm 6178,9)$, namun peningkatan ekspresi relatif mRNA LMP1 EBV tidak bermakna secara statistik Ekspresi relatif mRNA LMP1 EBV dari biopsi jaringan tumor FFPE berpotensi sebagai biomarka progresivitas tumor pada stadium lanjut KNF tidak berdiferensiasi.
\end{abstract}

Kata kunci : ekspresi relatif mRNA LMP1 EBV, biopsi jaringan FFPE, biomarka progresivitas tumor, KNF tidak berdiferensiasi (KNF WHO-III) 


\section{Pendahuluan}

Insidensi KNF tertinggi di seluruh dunia terjadi di wilayah Asia Tenggara, terutama Malaysia, Indonesia dan Singapura. Pada umumnya insidensi KNF tinggi ditemukan pada penduduk populasi etnis Cina dan Melayu (Jemal, 2011). ${ }^{1}$ Populasi Indonesia mempunyai keragaman etnik tinggi dengan jumlah penduduk berkisar 225 juta jiwa dengan angka insidensi KNF sebesar 6,2 per 100.000 penduduk per tahun (Soeripto, 1998; Steven et al., 2006)., ${ }^{2,3}$ KNF merupakan tumor kelima terbesar pada manusia, setelah tumor ganas serviks uteri, payudara, getah bening, dan kulit. KNF merupakan tumor ganas kepala dan leher yang terbanyak ditemukan sebesar 60 persen kasus. Frekuensi pasien KNF ditemukan hampir merata di seluruh Indonesia (Roezin\&Adham, 2007). ${ }^{4}$

Infeksi virus Epstein-Barr (EBV) telah terbukti konsisten dengan timbulnya KNF (Roezin, 1999). ${ }^{5}$ EBV mempunyai dua fase dalam daur infeksinya yaitu fase litik dan laten. Pada fase laten daur infeksi EBV hanya sedikit gen laten yang diekspresikan, sehingga jumlah kopi DNA virus dipertahankan dalam tingkat yang relatif rendah dan tidak diproduksi virion (partikel virus). Pada fase litik daur infeksi EBV terjadi serangkaian ekspresi gen litik, replikasi genom virus dan produksi virion (Chang et al., 2004; Kieff and Rickinson, 2001; Metzenberg, 1990). ${ }^{6-8}$

Klasifikasi UICC dan AJCC yang pada umumnya sama untuk semua keganasan, kecuali untuk keganasan kelenjar liur dan tiroid Saat ini, penentuan stadium TNM untuk ukuran tumor (T), keterlibatan kelenjar getah bening $(\mathrm{N})$, dan metastasis (M) ditentukan berdasarkan Union for International Cancer Control (UICC) Tahun 2010 untuk semua pasien berdasarkan penilaian klinis dan pemindaian tomografi komputer sebagai bagian manajemen pasien rutin (Cancer American Joint Committee on. Pharynx). ${ }^{9}$ Indonesia sebagai daerah endemik KNF nampaknya faktor infeksi EBV berperan lebih dominan sebagai penyebab timbulnya KNF. Pengukuran aktivitas mRNA EBV di lokasi tumor primer secara langsung pada daerah nasofaring perlu dilakukan, karena aktivitas mRNA EBV lebih mencerminkan patogenesis KNF yang sesungguhnya daripada diagnosis serologi dan pengukuran kuantitas cellfree DNA EBV (viral load DNA EBV) dalam serum/plasma penderita KNF (Steven et al., 2005). ${ }^{10}$ Infeksi EBV pada KNF menunjukkan pola infeksi fase laten II yang antara lain mengekspresikan gen LMP1 dan EBNA1, sehingga ekspresi gen ini sering digunakan untuk petanda biologi infeksi EBV pada KNF (Barnes et al., 2005). ${ }^{11}$ Tujuan penelitian ini adalah mengetahui potensi ekspresi relatif mRNA LMP1 EBV sebagai biomarka progresivitas tumor pada KNF tidak berdiferensiasi (KNF WHO-III).

\section{Metode}

Rancangan penelitian ini adalah penelitian analitik observasional yang berbentuk studi seran lintang (cross sectional). Sampel penelitian ini adalah biopsi jaringan tumor penderita $\mathrm{KNF}$ tidak berdiferensiasi dalam blok parafin (embedded paraffin) dengan penegakan diagnosis pasti dari hasil pemeriksaan pada Departemen Patologi Anatomi dan penegakan stadium dari pemerikasaan pada Departemen Radioterapi, RSUD Prof dr Margono Soekarjo, Purwokerto. Berdasarkan atas proporsi jumlah pasien KNF dibandingkan dengan kanker lain adalah 5,46 persen (Incidency Primary Cancer in Indonesia Pathology Base, 1990), maka besar sampel minimal yang diperlukan dalam penelitian ini adalah 20 orang (Sastroasmoro, 2005). ${ }^{12}$

Biopsi jaringan tumor penderita KNF dalam blok parafin (embedded paraffin) dilakukan isolasi dengan PureLink FFPE (formalin-fixed paraffinembedded) RNA isolation kit (Invitrogen) hingga diperoleh $100 \mu \mathrm{L}$ larutan RNA. Sintesis cDNA dilakukan dengan protokol Super Script III First Strand System kit 
(Invitrogen). Larutan cDNA yang diperoleh dapat segera digunakan untuk analisis RT-qPCR atau disimpan pada suhu $-20^{\circ} \mathrm{C}$. Pada campuran RT-qPCR (PCR mix) sebaiknya digunakan template cDNA sebesar 10 persen dari total volume.

Teknik RT-qPCR digunakan untuk mengukur ekspresi relatif mRNA LMP1 EBV pada sampel penderita KNF dengan primer sisi kiri (left/forward primer) adalah 5'-GGAGATTCTCTGGCGAC T TG-3' dan primer sisi kanan (rigth/reverse primer) adalah 5'-GAGCCAAAGGAGAT CAACCA-3' (accession number NC_0093 34.1, GeneID: 5176215) (Wahyono, 2017). ${ }^{13}$ Primer gen GAPDH (glyceralde hyde-3-phosphate dehydrogenase) sebagai gen house-keeping yang berfungsi untuk normalisasi nilai $\mathrm{Ct}$ (cycle threshold) dengan primer sisi kiri (forward/left primer) adalah 5'-GAAGGTGAAGGT CGGAGT-3'dan primer sisi kanan (reverse/right primer) adalah 5'GAAGATGGTGATGGGATT TC-3'. Campuran qPCR (qPCR mix) dibuat dalam volume $20 \mu \mathrm{L}$ (DyNAmo Flash SYBR Green qPCR Kit, Thermo Scientific) dengan komposisi terdiri dari : $2 \mathrm{X}$ Master mix, $0,5 \mu \mathrm{M}$ primer forward, $0,5 \mu \mathrm{M}$ primer reverse dan $100 \mathrm{ng}$ cetakan cDNA. Amplifikasi dilakukan pada mesin realtime PCR (Bioer, LineGene K FQD 48A) sebanyak 40 siklus dengan kondisi PCR sebagai berikut : denaturasi awal $95{ }^{\circ} \mathrm{C}$ selama 7 menit, denaturasi $95{ }^{\circ} \mathrm{C}$ selama 15 detik, penempelan primer dan pemanjangan $60 \quad{ }^{\circ} \mathrm{C}$ selama 30 detik. Pengukuran konsentrasi cDNA sampel dilakukan dengan nanodrop spektrofotometer (NanoOne version 4262 V1.7.3). Ekspresi relatif mRNA LMP1 EBV dihitung berdasarkan atas rumus $2^{-\Delta \mathrm{Ct}}$ $=\left[\mathrm{Ct}_{(\mathrm{LMP} 1)}-\mathrm{Ct}_{(\mathrm{GAPDH})}\right]$ (Livak and Schimttgen, 2001; Shaib et al ). ${ }^{14,15}$ Housekeeping genes adalah gen yang ekspresinya tidak berubah dalam kondisi eksperimen. Gen GAPDH (Glyceraldeyde3-phosphat dehydrogenase) : house keeping gene yang ekspresinya paling stabil, sehingga digunakan sebagai kontrol internal dalam RTq-PCR (Barber et al., 2005). ${ }^{16}$ Analisis statistik dilakukan untuk menyajikan analisis Box Plot nilai median ekspresi relatif mRNA LMP1 EBV dengan program SPSS versi 16.0 berdasarkan atas pengelompokan stadium KNF.

\section{Hasil}

Ekspresi relatif mRNA LMP1 EBV sampel penelitian dihitung berdasarkan atas perhitungan dengan rumus $2^{-\Delta \mathrm{Ct}}=$ $\left[\mathrm{Ct}_{(\mathrm{LMP1})}-\mathrm{Ct}_{(\mathrm{GAPDH})}\right]$. Nilai ekspresi relatif mRNA LMP1 EBV pada penderita KNF tidak berdiferensiasi berkisar 5,832.90 39,786.70 (Tabel 1) sebagai berikut : 
Tabel 1

Nilai ekspresi relatif mRNA LMP1 EBV dan stadium KNF WHO-3

\begin{tabular}{lccrrrc}
\hline Nomor & Grup & $\begin{array}{l}\text { Nilai } \\
\text { Ct }\end{array}$ & Nilai $\Delta \mathbf{C t}$ & $\begin{array}{c}\text { Nilai } \\
\mathbf{2}^{-\Delta \mathbf{C t}}\end{array}$ & $\begin{array}{r}\text { Kategori } \\
\text { Ekspresi } \\
\left(\mathbf{2}^{-\Delta \mathbf{C t}}\right)\end{array}$ & Stadium \\
\hline <A1> & 1 & 20,45 & 13,55 & $11.993,80$ & overekspresi & IV \\
<A2> & 1 & 20,99 & 13,01 & 8.249 & overekspresi & - \\
<A3> & 1 & 20,93 & 13,07 & $8.599,30$ & overekspresi & - \\
<A4> & 1 & 18,93 & 15,07 & $34.397,10$ & overekspresi & - \\
<A5> & 1 & 21,49 & 12,51 & $5.832,90$ & overekspresi & III \\
<A6> & 1 & 20,22 & 13,78 & $14.066,70$ & overekspresi & IVB \\
<A7> & 1 & 21,12 & 12,88 & $7.538,20$ & overekspresi & - \\
<A8> & 1 & 20,86 & 13,14 & $9.026,80$ & overekspresi & IVC \\
<A9> & 1 & 20,56 & 13,44 & $11.113,30$ & overekspresi & IVA \\
<A10> & 1 & 20,39 & 13,61 & $12.503,10$ & overekspresi & - \\
<A11> & 1 & 18,72 & 15,28 & $39.786,70$ & overekspresi & - \\
<A12> & 1 & 20,55 & 13,45 & $11.190,60$ & overekspresi & - \\
<A13> & 1 & 19,5 & 14,5 & $23.170,50$ & overekspresi & - \\
<A14> & 1 & 20,36 & 13,64 & $12.765,80$ & overekspresi & III \\
<A15> & 1 & 20,74 & 13,26 & $9.809,70$ & overekspresi & IVA \\
<A16> & 1 & 20,61 & 13,39 & $10.734,70$ & overekspresi & - \\
<A17> & 1 & 20,94 & 13,06 & 8539,90 & overekspresi & - \\
<A18> & 1 & 20,57 & 13,43 & 11036,50 & overekspresi & - \\
<A19> & 1 & 19,62 & 14,38 & $21.321,20$ & overekspresi & - \\
<A20> & 1 & 19,35 & 14,65 & $25.709,30$ & overekspresi & IVA \\
\hline
\end{tabular}

Dari ke 20 sampel penelitian hanya 8 subyek (individu) yang dapat ditegakkan stadium tumornya yang terdiri dari stadium III (2 individu) dan stadium IV (6 individu). Pada penderita KNF
WHO-3, ekspresi relatif mRNA LMP1 EBV dengan stadium III adalah median 9.299,35 (5.832,9 - 12.965), sedangkan stadium IV median 11.553,55 (9.026,8 25.709,3) (Gambar 1). 


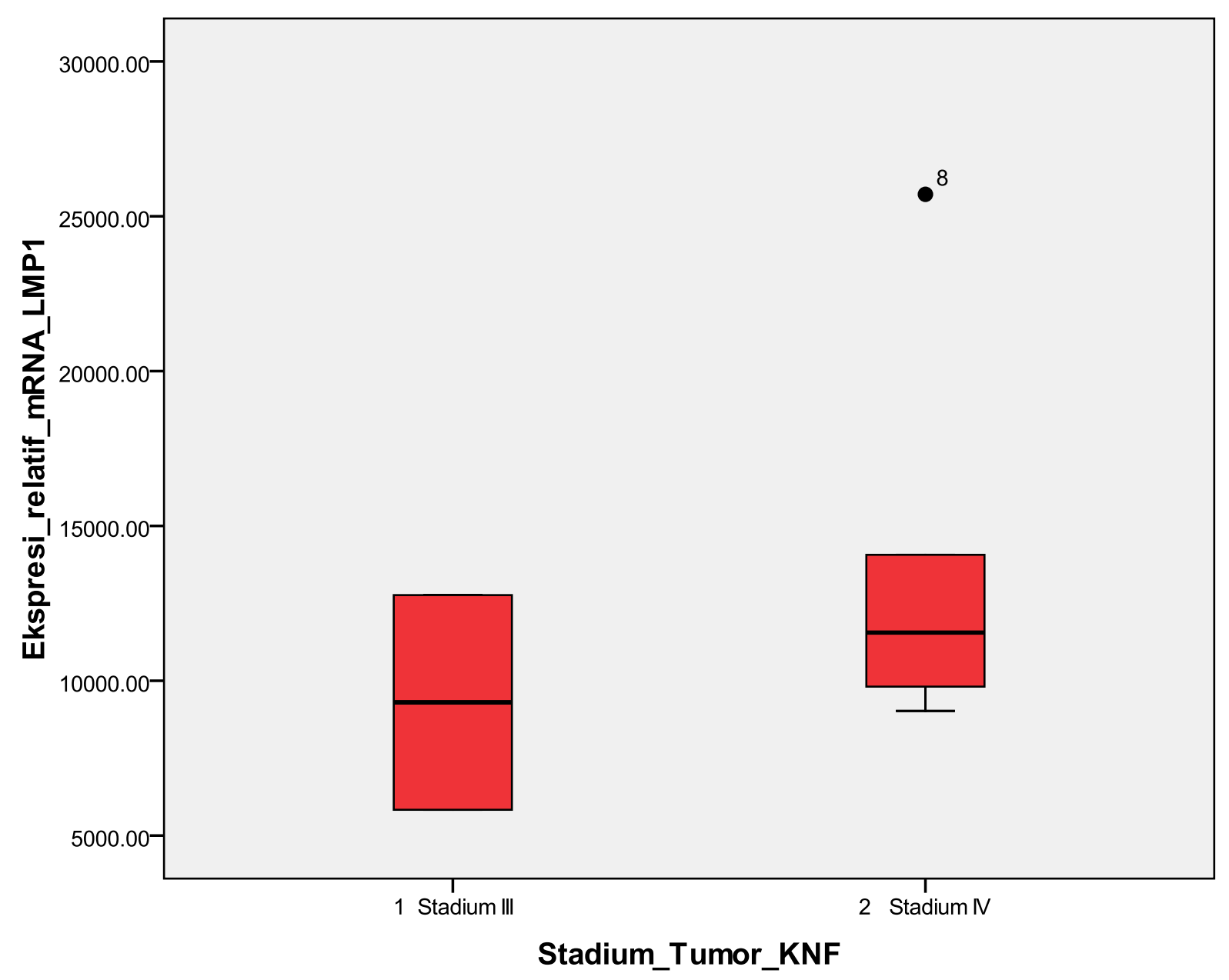

Gambar 1 Hasil analisis Box-Plot ekspresi relatif mRNA LMP1 EBV pada stadium III : nilai median 9.299,35 (5.832,9-12.965) dan stadium IV : nilai median 11.553,55 (9.026,8-25.709,3) penderita KNF tidak berdiferensiasi (KNF WHO-III).

Hasil analisis statistik dengan uji $\mathrm{T}$ independen (SPSS version 17) menunjukkan nilai ekspresi relatif mRNA LMP1 EBV pada stadium IV $(\mathrm{n}=6$; $13.619,33 \pm 4902,3)$ meningkat 1,5 kali dibandingkan dengan stadium III $(\mathrm{n}=2$; 9.299,35 $\pm 6178,9)$, namun peningkatan ekspresi relatif mRNA LMP1 EBV tidak bermakna secara statistik $(\mathrm{n}=8$; $\mathrm{df}=1$; $p<0,826$ ).

\section{Pembahasan}

Studi terdahulu telah memperlihatkan bahwa ekspresi mRNA LMP1 EBV pada jaringan biopsi tumor FFPE dari penderita
KNF tidak berdiferensiasi (KNF WHO-III) dengan metode RT-PCR sebesar 51.9 persen (Wahyono et al., 2017). ${ }^{12}$ Nilai ekspresi relatif mRNA LMP1 EBV penderita KNF tidak berdiferensiasi dengan nilai median stadium III sebesar 9.299,35 dan stadium IV sebesar 11.553,55 menunjukkan nilai ekspresi yang sangat tinggi (overekspresi), karena nilai ekspresi $>2$ dikategorikan tinggi dan nilai ekspresi >100,0 dikategorikan overekspresi. Ekspresi relatif mRNA juga bervariasi mulai nilai ekspresi yang rendah pada stadium awal hingga nilai ekspresi 
sangat tinggi (overekspresi) pada stadium lanjut pada KNF (Dewi et al., 2016). ${ }^{17}$

Penelitian terdahulu juga memberikan bukti kuat bahwa patogenesis KNF terkait erat dengan infeksi EBV, karena hingga 70 persen pasien dengan KNF adalah LMP1EBV positif (Mubarika et al, 2012). ${ }^{18}$ Ekspresi LMP1 diaktifkan oleh BRLF1 (R) segera protein awal (IE) dalam sel yang terinfeksi fase litik. Ekspresi LMP1 dipromosikan oleh diferensiasi dan secara positif mengatur reaktivasi virus litik di NPC dan meningkatkan efek litik yang disebabkan oleh diferensiasi sel epitel (Narwandar et al.,2017). LMP1 hanya diekspresikan pada sel neoplastik (tumor) saja, namun LMP1 tidak diekspresikan pada sel epitel normal. LMP1 diekspresikan pada mayoritas penderita lesi pre-maligna pada permukaan jaringan tumornya. ${ }^{19}$ Hanya sekitar 3\% RNA yng diisolasi dari blok parafin untuk mendapatkan sintesis cDNA, dibandingkan dengan penggunaan sampel fresh frozen.Penggunaan dengan analisis formalin-fixed parafin-embedded (FFPE) sering mengalami kesulitan, karena RNA yang diekstrak dari jaringan FFPE sering secara signifikan terdegradasi. Penambahan PBS washing step saat preparasi spesimen untuk ekstraksi RNA dari spesimen FFPE secara signifikan meningkatkan kualitas RNA. Luasan jaringan yang digunakan untuk ekstraksi dan usia blok parafin, tidak berpengaruh terhadap kualitas RNA dan primer yang digunakan untuk sintesis cDNA juga tidak berpengaruh terhadap kualitas cDNA untuk amplifikasi PCR (Goeiva). ${ }^{20}$

Hasil penelitian ini yang menunjukkan peningkatan ekspresi relatif mRNA LMP1 EBV sebesar 1,5 kali pada stadium IV $(3.619,33 \pm 4902,3)$ dibandingkan dengan stadium III $(9.299,35 \pm 6178,9)$ pada penderita KNF tidak berdiferensiasi (KNF WHO-III), walaupun peningkatan ekspresi relatif mRNA LMP1 EBV ini tidak bermakna secara statistik (niai $\mathrm{p}<0,826$ ). Ekspresi LMP1 tinggi secara in vivo berkaitan erat dengan prognosis KNF yang buruk. Oleh karena itu, LMP1 merupakan gen EBV yang berperan penting dalam transformasi sel normal menjadi sel tumor melalui mekanisme sebagai berikut : pertama, LMP1 menginduksi transformasi sel B yang berkaitan dengan infeksi EBV primer; kedua, LMP1 menghambat apoptosis sel B dengan menginduksi molekul bcl-2 (anti apoptosis) dan A20; ketiga, LMP1 akan menyebabkan peningkatan sitokin IL-10 yang berperan menstimulasi proliferasi sel $\mathrm{B}$ dan menghambat respon imun lokal (Middledorp et al., 2003). ${ }^{21}$ Mayoritas penderita KNF pada saat didiagnosis sudah dalam stadium lanjut (stadium III dan IV) sebesar 86,1 persen memberikan gambaran bahwa pengetahuan dan kesadaran terhadap gejala klinis awal KNF yang rendah dari penderita KNF maupun dokter pada tingkat Puskesmas (Fles et al., 2010). ${ }^{22}$ Demikian pula, gejala klinis awal KNF yang nampak mirip dengan gangguan pilek biasa yang disertai rasa tidak nyaman, sehingga KNF banyak yang terlambat didiagnosis karena tidak memiliki gejala spesifik dan letak nasofaring yang tidak mudah diperiksa oleh dokter yang bukan ahlinya (Susworo, 2004; Brennan, 2006). ${ }^{23,24}$ Oleh karena, pada stadium lanjut KNF (stadium III dan IV) menunjukkan terjadi progresivitas tumor pada KNF, maka ekspresi relatif mRNA LMP1 EBV berpotensi sebagai biomarka progresivitas tumor KNF tidak berdiferensiasi stadium lanjut.

\section{Kesimpulan}

Berdasarkan penelitian yang telah dilakukan selama ini dapat disimpulkan ekspresi relatif mRNA LMP1 EBV dari biopsi tumor FFPE berpotensi sebagai biomarka progresivitas tumor pada KNF tidak berdiferensiasi (KNF WHO-III).

\section{Saran}

Penelitian ini perlu dilanjutkan dengan melakukan eksplorasi biomarka prognosis 
KNF dengan analisis ekspresi gen baik pada EBV maupun sel kanker yang berkaitan karsinogenesis dan metastasis tumor.

\section{Ucapan Terima Kasih}

Peneliti mengucapkan terima kasih kepada: Dirjen Dikti, Kementerian Riset, Teknologi dan Pendidikan Tinggi sebagai penyandang dana penelitian Hibah Fundamental 2015-2016, Ketua LPPM UNSOED sebagai pengelola dana penelitian ini, Direktur RSUD Prof. dr. Margono Soekarjo, Kepala Departemen Patologi Anatomi - RSUD Prof. dr. Margono Soekarjo/FK Unsoed dan Kepala Departemen Radioterapi - RSUD Prof. dr. Margono Soekarjo/FK Unsoed.

\section{Daftar Rujukan}

1. Jemal A, Bray F, Center CC, Ferlay J, Ward E, Forman D. Global cancer statistics. Ca Cancer J Clin. 2011; 61: 69-90.

2. Soeripto. Epidemiology of nasopharyngeal carcinoma. Berita Kedokteran Masyarakat.1998; XIII : 207-11.

3. Steven SJC, Verkuijlen SAWM, Hariwiyanto B, Harijadi, Paramita DK, Fachiroh J, Marlinda Adham, Tan IB, Haryana SM, Middeldorp JM. Noninvasive diganosis of nasopharyngeal carcinoma : nasopharyngeal brushing reveal high Epstein-Barr virus (EBV) DNA load and carcinoma-specific viral BARF1 mRNA. Int J Cancer. 2006; 119: 608614.

4. Roezin A dan Adham M. Karsinoma Nasofaring. Dalam : Soepardi EA, Iskandar N, Bashiruddin J, Restuti RD, editor. Buku Ajar Ilmu Kesehatan : Telinga Hidung Tenggorok Kepala dan Leher Edisi ke 6. Jakarta : Balai Penerbit FKUI; 2007.

5. Roezin A. Berbagai faktor penyebab dan predisposisi karsinoma nasofaring. Maj Kedokt Indon. 1999; 49(3): 85-88.

6. Chang Y, Chang SS, Lee HH, Doong SL, Takada K, Tsai CH. Inhibition of the EpsteinBarr virus lytic cycle by Zta-targeted RNA interference. J Gen Virol. 2004; 85: 371-1379.

7. Kieff E and Rickinson AB. Epstein-Barr virus and Its Replication. In : Virology. 4th ed. Fields BN, Knipe DM, Howley PM, editors. Philadelphia : Lippincott-Raven; 2001. p. 2511-73.
8. Metzenberg S. Levels of Epstein-Barr virus DNA in lymphoblastoid cell lines are correlated with frequencies of spontaneous lytic growth but not with level of expression of EBNA-1, EBNA-2, or latent membrane protein. J Virol.1990; 64: 473-444.

9. Cancer American Joint Committee on. Pharynx (Including Base of Tounge, Soft Palate, and Uvula) in Stephen Edge, et al. (eds.), AJCC Cancer Staging Manual ( $7^{\text {th }}$ ed); New York, Springer-Verlag 2010: 33-45. (13)

10. Steven SJC, Verkuijlen SAWM, van den Brule AJC, Middeldorp JM. Comparison of quantitative competitive PCR with LC-based PCR for monitoring of Epstein-Barr virus (EBV) DNA load in clinical specimens. J Clin Microbiol. 2005; 40: 4105-13.

11. Barnes L, Eveson JW, Reichart P, Sidransky D (Eds.): World Health Organization Classification of Tumours. Pathology and Genetics of Head and Neck Tumours. Lyon : IARC Press; 2005. p.85-97

12. Sastroasmoro S dan Ismael S. Dasar-dasar Metodologi Penelitian Klinis. Edisi ke-3. Jakarta : CV Sagung Seto; 2011.

13. Wahyono DJ, Gumilas NSA, Sulistyo H. The Expression of mRNA LMP1 Epstein-Barr Virus from FFPE Tumour Biopsy: a Potential Biomarker of Nasopharyngeal Carcinoma Diagnosis. Biosaintifika: Journal of Biology \& Biology Education 2017; 9 (2) : 357-362 (15)

14. Livak KJ, Schmittgen TD (2001). Analysis of relative gene expression data using real-time quantitative PCR and the 2(-Delta Delta C(T)) Method. Methods 25(4):402-8.

15. Shahib MN, Budiman, Feranty ZA (2015). Studies on Gene Expressions at the RNA Level Associated with the Senile Lens Changes in Human Lens Cataract. Donnish J. Med. Med. Sci. 2(3):011-8.

16. Barber RD, Harmer DW, Coleman RA, Clark BJ. GAPDH as a housekeeping gene: analysis of gapdh mRNA expression in a panel of 72 human tissues. Physiol Genomics. 2005. 20 September 2011. (doi:10.1152/physiolgenomics.00025.2005)

17. Dewi YA, Ahwil C, Nurhalim S. The role of myeloid derived suppressor cells and CXCR4 genes expression for nasopharyngeal carcinoma progression. J Sci Res Stud 2015; 2(8): 195-201. (14)

18. Savitri E, Mubarika SH (2012). Viral load Epstein-Barr Virus profiling andAntibodi IgA (VCA-P18+EBNA-1) titer of Nasofaringeal Carcinoma in Makassar dan Yogyakarta. J. Indon. Med. Assoc. 2012; 62(5):174-177. (16)

19. Nawandar DM, Ohashi M, Djavadian R, Barlow E, Makielski K, Ali A, Lee D, Lambert PF, Johannsen E, Kenney SC. 
Differentiation-Dependent LMP1 Expression Is Required for Efficient Lytic Epstein-Barr Virus Reactivation in Epithelial Cells. J Virol. 2017 ; 91(8). pii: e02438-16. doi: 10.1128/JVI.02438-16. Print 2017 Apr 15.(17)

20. Gouveia, G.R., Ferreira, S.C., Ferreira J.E., Siqueira, S.A.C., Pereira, J. (2014). Comparison of Two Methods of RNA Extraction from Formalin-Fixed ParaffinEmbedded Tissue Specimens. Biomed Research International.

21. Middeldorp, J.M., Brink, A.A.T.P., van den Brule, A.J.C., Meijer, C.J.L.M. (2003). Pathogenic roles for Epstein-Barr virus (EBV) gene products in EBV-associated proliferative disorders. Crit Rev Oncol Hematol, 45 : 1-36.

22. Fles R, Wilderman MA, Sulistiono B, Haryana SM, Tan IB. Knowledge of general practioners about nasopharyngeal cancer at Puskesmas in Yogyakarta, Indonesia. BMC Medical Education 2010; 10 (81).

23. Susworo R. Kanker nasofaring : epidemiologi dan pengobatan mutahkhir. Cermin Dunia Kedokteran. 2004; 144: 16-9.

24. Brennan B. 2006 Carcinoma Nasopharyngeal. Orphanet J Rare Dis. 2006; 1(23): 1-7. 